IRSH 63 (2018), Special Issue, pp. 89-107 doi:10.1017/S0020859018000238 (C) 2018 Internationaal Instituut voor Sociale Geschiedenis

\title{
Ethnoscapes of Exile: Political Prisoners from Indochina in a Colonial Asian World*
}

\author{
L ORRAINE M. PATERSON \\ School of History, Politics and International Relations \\ University of Leicester \\ University Road, Leicester $L E_{I} 7 R H, U K$
}

E-mail: lp283@leicester.ac.uk

\begin{abstract}
During the French colonization of Indochina (I863-I954), approximately 8,000 prisoners - many of them convicted of political crimes - were exiled to twelve different geographical locations throughout the French empire. Many of these prisoners came from a Chinese background or a culturally Chinese world, and the sites to which they were exiled (even the penal colonies themselves) contained diasporic Chinese communities. Knowing Chinese might be their greatest asset, or being able to "pass" as Chinese the most valuable tool to facilitate escape. This article explores a group of political prisoners sent from French Indochina to French Guiana in 1913 and their subsequent escape, with the aid of Chinese residents. If exile is, in one sense, the ultimate exercise of colonial power - capable of moving bodies to distant locales - examining these lives through a Vietnamese lens reveals a very different story than the colonial archival record reflects.
\end{abstract}

In I923, in the British colony of Trinidad, a young English woman returned from visiting her family in a suburb of the capital, Port of Spain, to find that her Chinese husband of six years, Lý Liễu, had packed up his possessions and left her and their two small children. ${ }^{\mathrm{I}}$ A Chinese trader, originally from Hong Kong, Lý had been working at a Chinese import/export company when this woman met and married him. ${ }^{2}$ Now, without warning or

\footnotetext{
* The research leading to these results has received funding from the European Research Council under the European Union's Seventh Framework Programme (FP/2007-2013) / ERC Grant Agreement 3 I 2542.

I. The figure of six years is cited by Nguyễn Văn Hầu, Chi sĩ Nguyễn Quang Diệu. Một lãnh tụ trọng yếu trong phong trào Đông Du miền Nam [Strong-willed Scholar Nguyễn Quang Diệu: A Key Leader in the Đông Du Movement in Cochinchina], Tựa của Nguyễn Hiển Lê [Preface by Nguyễn-Hiển Lê] (Saigon, I964), p. 59.

2. As is customary in Vietnamese names, the family name comes first. For citations containing the family name Nguyễn, the usual historical convention of citing the given name will be used (due to the overwhelming number of individuals with the surname Nguyễn).
} 
explanation, he had vanished, presumably to return to Hong Kong. Indeed, he never returned to Trinidad or saw her, or their children, again. In his later reminiscences, Lý did not refer to his wife or children by name, but conveyed his terrible guilt at having abandoned them. In a less predictable regret, Lý expressed sadness that his wife would forever assume he was racially Chinese and would never know his real race and identity. ${ }^{3}$ For, despite his appearance, his fluency in Cantonese, his position at a Chinese company, and his years spent in Hong Kong, he was not the overseas Chinese businessman he pretended to be. In fact, he was an escaped Vietnamese political prisoner from the notoriously harsh penal colony of French Guiana, about seventeen days away from Port of Spain by boat.

Such a story goes against the stereotype of the penal colony of French Guiana, usually positioned as a hellish prison from which escape was nigh on impossible. Its horrific reputation was encapsulated by its name among prisoners, and eventually the general public: the guillotine sèche, the "dry guillotine”, as it killed slowly, but just as surely, as a guillotine. ${ }^{4}$ Films like Papillon (1973) depict the extraordinary lengths to which prisoners had to go to escape; impersonating a Chinese businessman was not one of them. ${ }^{5}$ The apparent ease with which Lý and his compatriots escaped from the supposedly secure penal colony of French Guiana to sail to Trinidad is striking. And they were not alone; their stories trace threads of "punitive mobility" that are not reflected at all in the colonial archival record. ${ }^{6}$

To understand how these exiles and subsequent groups of Vietnamese prisoners engineered their escapes, and reclaimed agency in their transportation, it is necessary to explore the skills they learned while circulating within a cosmopolitan East Asian world. A world they inhabited at the beginning of the twentieth century as they sought expertise, which they strategically applied to the predicament of exile and imprisonment. Narrating their histories is undoubtedly a perspective from the colonies, one that is about the unique world - and resources - of East Asian convicts in the colonial French empire. However, it also shows the societal and penal layers of French Guiana refracted through a different lens, which is not just from the colonial perspective or using the sources of the archival apparatus of the colonial power to mould the historical narrative. Examining the lives of these exiles reveals that the ability of the colonial state to act as a

3. Nguyễn Văn Hầu, "Lý Liễu và phong trào đại đông du" ["Lý Liễu and the Study East Movement”] Bách Khoa, CXXXXV (1963), pp. 39-49.

4. This phrase inspired the title of René Belbenoit's memoir, Dry Guillotine: Fifteen Years among the Living Dead (New York, 1938), one of the most famous memoirs of French Guiana. Such was its popularity that it went through fourteen printings the year it was published.

5. The film Papillon was based on a 1970 book of the same title by escaped convict Henri Charrière.

6. Introduction to this special issue, p.2. 
surveillance apparatus was often far more limited than imagined. French authorities were often unable to police boundaries between prisoners from Indochina and the resident Chinese communities in the penal sites. Many Vietnamese prisoners came from an ethnically Chinese background, or a culturally Chinese world, and the sites to which they were exiled (even the penal colonies themselves) contained diasporic Chinese communities. For many prisoners, knowing Chinese was their greatest asset or being able to "pass" as Chinese the most valuable tool to facilitate escape. Arguably, for many of these prisoners, the ethnoscapes of their exile were not as unfamiliar a world as the French authorities had intended. As well as being within a penal context, they were within the cultural and linguistic milieu of the Chinese diaspora - a diaspora that traversed both French and British colonial boundaries.

Colonial scholarship concerned with colonial projects has largely focused on connections between the metropole and the colonies as opposed to intercolony exchange. This article seeks to make connections from Indochina within a wider world of transcolonial constraint and mobility. Some connections were new, while others have historical roots. In this case, the historic flows and circulations between southern China and Vietnam were transposed to a new - Caribbean - context. Therefore, this article moves beyond notions of imperial centre and colonial penal periphery by examining South-South connections and by examining these prisoners' lives beyond the stream of scholarship on colonial institutions of incarceration. Exploring their exilic trajectory from their perspective, and not through a colonial lens, tells an entirely different historical story; one that does not end in French Guiana with one-page prisoner dossiers, but instead with a historical narrative that indicates "expressing choice and identity in the most unpromising of penal circumstances". ${ }^{7}$

A caveat: undeniably, these prisoners' stories are not the stories of all prisoners within the often brutal penal colony of French Guiana. Many prisoners - Indochinese or other - experienced aspects of the violence and despair of the "dry guillotine" just as the memoirs described. As the Introduction to this special issue indicates, "to speak of punitive sites as 'contact zones' is not to downplay the brutality of convict labour regimes". ${ }^{8}$ However, the penal colony was not monolithic. Different sites of imprisonment, different racial backgrounds, and different temporal periods of confinement all reveal the diversity of punishment, captivity, and agency within one penal colony and its various penal sites. To be able to trace these threads, it is necessary to look at this historical narrative from the Vietnamese perspective. 


\section{THE SOCIETY FOR THE ENCOURAGEMENT OF LEARNING}

The leafy campus of St Joseph's College, an elite Catholic secondary school in Hong Kong, founded in I 875 and still enrolling students today, seems an unlikely place for a meeting that ultimately led to Lý Liễu's double life in Trinidad. Lý was sent there in I905 at the age of twelve, his forward-looking father determined that Lý should benefit from a cosmopolitan education. Vietnam's colonized status was greatly resented by many Vietnamese, who sought wider East Asian milieus - especially Hong Kong and Yokohama in Japan - in which to organize anti-colonial activities. For Vietnam, a shared intellectual history with China meant that locations in southern China were the logical sites of such interactions. Indeed, it was at St Joseph's College that Lý met anti-French activists, and by the time he was fifteen he had joined a group with the innocuous name of "Khuyến Du Học Hội" "The Society for the Encouragement of Learning"), hereafter KDHH. ${ }^{9}$ After leaving St Joseph's College, Lý studied at a Centre for English Studies in Hong Kong, while helping students clandestinely arriving from Vietnam and assisting with the broader anti-colonial effort directed by Vietnamese nationalists in various South East- and East Asian countries.

Another key member of the KDHH was Nguyễn Quang Diêu, who was born, in I 880, in a small village in Sa Đéc province, southern Vietnam, into a family of Confucian scholars. ${ }^{\circ}$ As was customary, Diêu began his studies of the Confucian classics at the age of six, and by ten he was known locally as a skilled writer. ${ }^{I}$ A glorious future in the Vietnamese civil service beckoned throughout his teenage years. However, Diêu eventually decided to break off studying the texts of the Vietnamese examination system, "apparently having concluded that clandestine fund-raising, recruitment, and distribution of propaganda held more possibility of saving his country than the most conscientious, sophisticated interpretation of the [Chinese] classics". ${ }^{\text {I2 }}$

Members of the KDHH spent their time travelling between Indochina and southern China (including Hong Kong) to circulate money and publications. However, these East Asian activities came to an end on I6 June I9I3, when British authorities in Hong Kong received a tip-off and Diêu and his colleagues were arrested at a supporter's house. The Consul of Hong Kong, Gaston Liebert, briefly mentioned their arrest in his private papers: "[S]ix Annamites have been arrested by the English police in Hong Kong where they went to make bombs. Ba Liễu, or Lý Liễu, a former

9. A so-called new learning group, the Society was dedicated to exploring philosophies and ideologies that would assist Vietnam in fighting against French colonialism.

Io. Nguyễn, Chi sĩ Nguyễn Quang Diệu.

I I. Ibid., p. I 2.

I 2. David Marr, Vietnamese Anticolonialism, I885-1925 (Berkeley, CA, I98I) p. 27. Study of the Confucian classics was a prerequisite to passing the Vietnamese examination system and becoming part of the Vietnamese civil service. 
student at St Joseph's school in Hong Kong, was one of them". ${ }^{13}$ Some reports indicated that bomb-making equipment was discovered in the house, which may be factual given British reticence to arrest Vietnamese without material evidence of criminal involvement. ${ }^{\mathrm{I}}$

Deportation to French Indochina followed and a criminal tribunal in Hanoi subsequently sentenced four of the group on 5 September I9I3. ${ }^{\text {Is }}$ Only one deportation dossier still exists in the French colonial archives, for a member of the Society called Đinh Hữu Thật, citing his crime as "criminal association". ${ }^{16}$ Such lack of documentation makes it difficult to determine why the length of their sentences varied dramatically: all were deported to French Guiana, but the sentences ranged from perpetual labour to five years (which was Lý's short sentence, perhaps on account of his youth?). However, they were all sentenced to relégation, i.e. following the completion of their sentences, under the law of relégation, they had to remain in French Guiana for the rest of their lives. Issuance of the sentences in I9I 3 meant the group was exiled just before the advent of World War I disrupted overseas deportation. ${ }^{17}$

\section{TRANSPORTATION, RACE, AND LABOUR}

Nguyễn Quang Diêu and Lý Liễu joined the stream of prisoners - both common-law and political - who travelled from French Indochina to various points throughout the French empire. Throughout the ninety-year French colonization of Indochina (I 863-I954), approximately 8,000 prisoners - many of them convicted of political crimes - were exiled to twelve different geographical locations. From Gabon to Guiana, there was hardly a corner of the French empire to which they were not sent. However, the exile location mostly depended on the category (and context) of the prisoner in question. Some prisoners required special surveillance (or, more rarely, special privilege). Different locales accepted different kinds of prisoners at different times. Sometimes, French territories submitted

I 3. Cornell University Libraries, Gaston Liebert Papers, Box 2: Dossier 7. Consul of France in Hong Kong to Governor-General of Indochina, 23 June 1913. This is the only reference to Lý Liễu by the name $\mathrm{Ba}$ Liễu. There is one other reference to the arrest of the group in Centre des Archives d'Outre Mer [hereafter, CAOM], GGI Indo/NF28, but no names are mentioned.

I4. French authorities were angered by British recalcitrance to arrest and deport without due evidence and process.

is. A criminal tribunal was the exception rather than the rule.

I6. CAOM, Đinh HữuThật’s dossier. Đinh Hữu Thật's name is misspelled as Dang Hun Thanh (with no diacritics), but the date, sentence, and exile locale all match, so I am assuming it is him. I7. Indeed, one of the reasons given for a formidable prison uprising in Thái Nguyên, northern Vietnam, in 1917 was that prisoners could not be deported to the penal colonies. See Peter Zinoman, The Colonial Bastille: A History of Imprisonment in Colonial Vietnam I862-1940 (Berkeley, CA, 200I), p. I 88. 


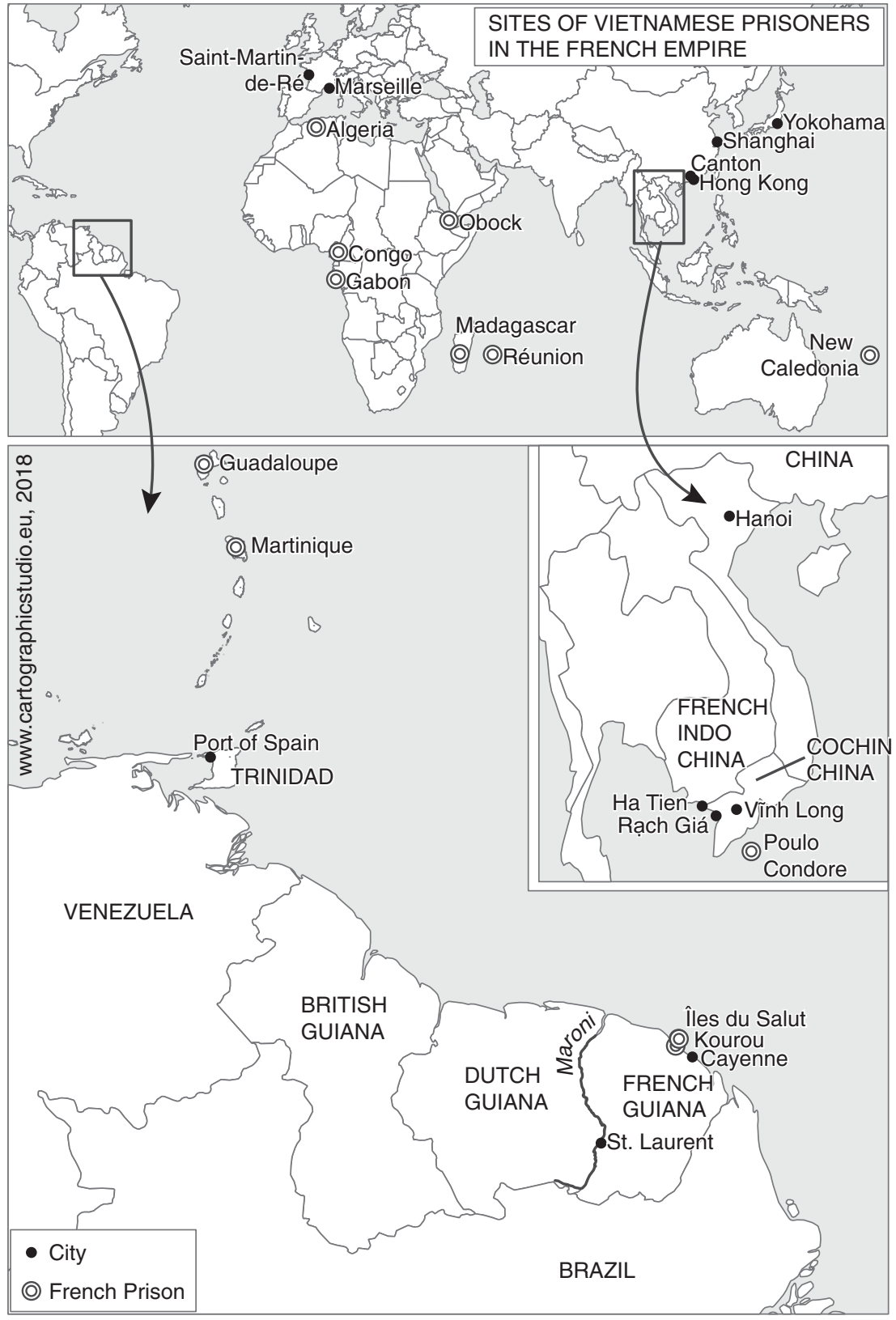

Figure I. Sites of Vietnamese prisoners in the French empire. 
requests for hard labour convicts for specific colonial projects and their requests may or may not have been granted. At different periods, prisoners from Indochina could be sent to the following exilic locales: Gabon, Congo (both incorporated into French Equatorial Africa in I910), Obock (later part of French Somaliland), French Guiana, New Caledonia, Madagascar, Réunion, Martinique, Guadeloupe, Algeria, and French Oceania (both Tahiti and the Marquesas). Some locations - Algeria, Tahiti, and the Marquesas were used only for elite political prisoners. Indeed, there were three key categories of prisoner: exiles, deported prisoners (political motivation), and transported prisoners (common-law prisoners). However, the categories blurred and overlapped in many ways. Prisoners were sent from Indochina for a variety of reasons, from serious criminal crimes like murder to suspected sedition against the colonial authorities. Confusion applied to the world of deportation and exile; those accused of political crimes and common criminals, forçats, were often placed in the same convoys and had similar fates. In that sense, being transported and being exiled were often synonymous, even if the terminology used was slightly different. Exiles required an exile decree, which had to stipulate the grounds for exile; additionally, a tribunal or trial might take place, but the decree was sufficient. Deportation came through the established French court or, as in September I9I3, a specially convened criminal commission.

French Guiana was the most common destination for prisoners from Indochina as they were considered constitutionally better equipped to withstand tropical diseases. ${ }^{18}$ Although exposure to malaria in the climates of Indochina could certainly assist in building up immunity, yellow fever was initially the most virulent (and often fatal) disease in French Guiana.

Situated on the northern coast of South America, French Guiana was established as a French settler colony in $1852 .{ }^{19}$ One reason for its selection as a site for penal settlements was the hope that this new role would stimulate its development after a disastrous French settlement had been attempted at Kourou. Prisoners seemed the next logical step. There was a desire to punish and a desire to reform and to re-socialize criminals so as to reinsert them into civil society. Out of this unresolved dichotomy evolved provisions for the transportation of certain categories of criminal to French

I8. It is difficult to estimate the overall number of deportees sent to French Guiana from Indochina given the inconclusive nature of the archive. French historian Danielle Donet-Vincent suggests that just under I, 000 deportees were sent from Indochina to French Guiana from I 885 to 1922: Danielle Donet-Vincent, "Les Bagnes des Indochinois en Guyane (193 I-1963)", OutreMer. Revue d'Histoire, 88:330-33 I (200I), pp. 209-22 I, available at http://www.persee.fr/doc/ outre_I63 I-0438_200I_num_88_330_3849; last accessed I 2 January 20I 8 . Donet-Vincent admits that it is impossible to know the breakdown between common-law prisoners and political prisoners.

19. Louis Lacroix, Les Derniers Voyages de Forçats et de Voiliers en Guyane, les Derniers Antillais (Paris, 1970). 
Guiana in I 852 (two years before an I 854 law officially created the bagne there) and then to New Caledonia. Although the intention was to punish the criminals, it was also assumed that they would be regenerated by life and work in a far-off rural environment, that their work would contribute strongly to the colony, and that the recidivist would be an agent in the service of France's larger colonial project. ${ }^{20}$

However, yellow fever meant French Guiana was an extremely difficult place in which to thrive, although the reason for the fever's prevalence was not understood until the end of the nineteenth century. ${ }^{21}$ Malaria also posed a big problem. Mortality rates were high, and in the first years of the penal colony between I 852 and I 866 close to forty per cent of all the convicts died. ${ }^{22}$ In 1867 , the government prohibited the transportation of French citizens to French Guiana. Only "African and Arab prisoners whose constitutions are resistant to the climate of the colony should be sent". ${ }^{23}$ New Caledonia was used instead for French prisoners until I 897, when there was some metropolitan debate that it had become too comfortable an exilic locale and French prisoners were again sent to French Guiana. Overall, 70,000 prisoners were sent to French Guiana and it operated as a penal colony until I952, with the last convicts arriving from France in 1937.

\section{JOURNEY TO THE JUNGLE}

Whether classified as political or common-law, prisoners from French Indochina were transported to French Guiana under similar conditions. The Society for the Encouragement of Learning group did not go directly to Cayenne, French Guiana's main town, but via Marseille and St Martin de Ré. ${ }^{24}$ From his two-week stay in a prison in Marseille, Diêu described the French city as an attractive port, organized in a very "civilized" way, rendering French treatment of colonized people even more perplexing. A poem Diêu claimed to have composed in Marseille refers to the fact that he found the justifications for his imprisonment opaque:

Heaven and earth give birth to us to have will

Not knowing at all what crime I have committed

Resign oneself without understanding

How is this the law of civilization? ${ }^{25}$

20. See Stephen A. Toth, "Colonisation or Incarceration? The Changing Role of the French Penal Colony in Fin-de-Siècle New Caledonia”, The Journal of Pacific History, 34:I (I999), pp. 59-74, 6I. 21. Idem, Beyond Papillon: The French Overseas Penal Colonies, I854-1952 (Lincoln, 2006).

22. Colin Forster, "Convicts: Unwilling Migrants from Britain and France", in David Eltis (ed.), Coerced and Free Migration: Global Perspectives (Stanford, CA, 2002), p. 284. Peter Redfield, Space in the Tropics: From Convicts to Rockets in French Guiana (Berkeley, CA, 2000), also quotes this statistic, p. 70. 23. CAOM, H/ Notice sur la transportation en Guyane et en Nouvelle Calédonie (1866-1867). 24. Nguyễn, Chi sĩ Nguyễn Quang Diệu, p. 5 I.

25. Ibid. 
From Marseille, the prisoners were sent to St Martin de Ré off La Rochelle in northern France, to await a biannual sailing. On the boat, they were locked into cages holding sixty to eighty people each, and made the journey in fifteen to twenty days, depending on whether the ship, the transportation vessel the Martinière, stopped in Algeria. In a later account, Lương Duyên Hồi, a Vietnamese prisoner, described the conditions on the Martinière. "The ocean waves were very high and many Vietnamese people on the boat were seasick". ${ }^{26}$ Unaccustomed to such rough seas, it was vital to remain vigilant for people falling unconscious from seasickness. ${ }^{27}$ Tensions on board could be exacerbated by the length of the exiles' sentences. For example, in I890, a convoy of I33 deportees from Indochina contained eighty prisoners sentenced to perpetual exile, which added to their "anxiety and tendency to disrupt". ${ }^{28}$ The Martinère deposited the prisoners on the Maroni River near Dutch Guiana. The largest prison camps in French Guiana, St Laurent and St Jean, were located near the Maroni River.

The convict population of French Guiana ranged between 3,000 and 7,000 prisoners; despite the arrival of some 700 new arrivals per year, deaths and attempted escapes kept the number of prisoners relatively constant. ${ }^{29}$ Following their arrival, French convicts were sorted by sentence category and then given work assignments accordingly. The convicts were almost all male; the high mortality among French women meant that their transportation ended in $1906 .^{3}$ Few women from Indochina were transported. Only ten Vietnamese women are recorded out of the 3,1 85 female dossiers extant in the archive, with no female Cambodians or Laotians listed. ${ }^{3 \mathrm{I}}$

Those designated as "recalcitrant" were assigned to cut down trees in the rainforest or sent to the Iles du Salut. Even here, a hierarchy emerged among the islands - on the Ile Royale, convicts were left relatively alone; those who attempted escape were sent to solitary confinement on the Ile du Diable [Devil's Island] was reserved primarily for European convicts - however, conditions there were generally better than on the Ile du Diable. ${ }^{32}$ In addition to these were the main camp at St Laurent, the notorious disciplinary camp of Charvin, and Camp Hatte, to which disabled prisoners were sent. Only the best-behaved convicts were allowed in Cayenne.

26. Lương Duyên Hồi, unpublished manuscript, in the possession of his grandson, Đỗ Thái Bình. 27. Ibid.

28. CAOM, Indo/NF76 I 890. The report also mentions that one convict had leprosy.

29. Redfield, Space in the Tropics, p.70. The number of prisoners varied subject to the time period examined.

30. Colin Forster, France and Botany Bay (Melbourne, 1992), p. 287. As mentioned before, mortality rates were also high for men, but did not cause as much consternation.

3 I. CAOM, Catalogue of Female Exiles to French Guiana.

32. Redfield, Space in the Tropics, pp. 79-80. Despite the islands being only fifteen kilometres from the shore, the voyage could take up to eighteen hours. 
In I 890, the Governor-General of French Guiana assured the Minister of Colonies that political prisoners from Indochina were immediately separated and given tasks commensurate with their sentences, but this assertion does not reflect other archival and anecdotal sources. ${ }^{33}$ Prisoners from Indochina almost always occupied one of three roles: domestic servant, agricultural worker, or fisherman. Indeed, the stereotype that Indochinese (especially Vietnamese) were diligent workers sometimes assisted them in getting lighter, less guarded, tasks. For example, Cambodians were often put into domestic agricultural work, including attempts at rice cultivation, considered less arduous than clearing forests. ${ }^{34}$ Throughout the I890s, Vietnamese convicts were allowed to build "Vietnamese-style" houses and had a virtual monopoly over fishing; catches were presumably used to supplement the meagre fare of the guards. ${ }^{35}$ On the Laussant Canal, which ran through Cayenne, it was reported that "the Vietnamese have formed a veritable village, where they help people with illnesses which are dealt with within the community". ${ }^{6}$

\section{THE HARBOUR OF CAYENNE}

For so long I've waited to see Cai Danh

As I glance upon the scenery, I am emotionally stirred.

The broad, vast sea courses with azure,

While green forests mist over the land. ${ }^{37}$

The landscape Diêu described in this poem - the scenery of "Cai Danh" - was not a port on the waterways of the Mekong Delta in southern Vietnam where he grew up, but rather the harbour of Cayenne. The emotions roused come at the end of an arduous voyage during which many of his fellow prisoners suffered terrible seasickness and "crossing the ocean for those unaccustomed to sea travel made them feel ill, especially at his advanced age". ${ }^{8}$

Diêu wrote the poem in a traditional Vietnamese poetic form: the luật thi, consisting of eight even syllable lines. As historian George Dutton points out: "The best-known poems in this [poetic] form were those produced by court officials who travelled to China on embassies to the Chinese court, poems that commented most frequently on the scenery but also on events of

33. This was the case at least until ı9го, when legal distinctions in Indochina became more defined. Prior to I9I0, there was no clear division between political and common-law prisoners. 34. CAOM, Indo/NF76, Letter from Governor-General of Guiana informing the Minister of Colonies that as soon as Cambodians arrived, they were instantly assigned an agricultural task.

35. From the archival record it is unclear what "Vietnamese-style" house means exactly.

36. The Laussant Canal was a dyke built in 1777 . CAOM, Indo/NF75.

37. A copy of the poem, titled "Cảm Tác Khi Đi Đày Đén Cai Danh", can be found in various locations, including Nguyễn, Chi sĩ Nguyễn Quang Diệu, p. 5 I.

38. Nguyễn, Chi sĩ Nguyễn Quang Diệu, p. I8. 
the journey" ${ }^{39}$ By rendering the unfamiliar into this familiar poetic scheme, Diêu laid claim to the landscape of French Guiana. He made legible to his (eventual) audience back in Vietnam this foreign topography. ${ }^{\circ}$ By creating a literary connection from exilic locale to homeland, Diêu was creating a punitive cultural circuit along which his eventual readers could travel.

Although the opening of the poem is framed by traditional Vietnamese poetic tropes, as it progresses it betrays more modern anxieties about the position of the Vietnamese in a world where countries have ceased to exist. After the opening lines, Diêu continues:

But barbaric catastrophes befall these people;

How much misery shall my own stock endure?

Extinction is mirrored glaringly before my eyes,

Witnessing the race, I shudder to think! ${ }^{41}$

The indigenous inhabitants of French Guiana are evoked in the penultimate lines as facing extinction. The use of the word chüng, "race", suggests Diêu was referring to the race inhabiting this "catastrophic" place: the Amerindians, indigenous inhabitants of French Guiana, rather than the annihilation of the penal colony detainees. ${ }^{4^{2}}$ The intricacies of a racially mixed Caribbean society were almost certainly lost on him. That Diêu refracted this landscape through a lens of Social Darwinism and fears of racial extinction is not surprising. ${ }^{43}$

Although Diêu later claimed to have penned this poem when he first saw the harbour of French Guiana, this is poetic licence. Supposedly moved to write by the scenery itself, he creates an allusion of the emotional moment of arrival and of horror. However, as mentioned above, convict ships arriving from St Martin de Ré did not dock at the harbour of Cayenne; they sailed to St Laurent du Maroni in western French Guiana, which was the main processing centre for prisoners arriving at the penal colony. It is also unlikely that Diêu saw any Amerindians at the harbour of St Laurent du Maroni; the arrival of the French had pushed them further and further inland.

39. George Dutton, "Crossing Oceans, Crossing Boundaries: The Remarkable Life of Philiphê Binh (1759-I 832)", in Tran Nhung Tuyet and Anthony Reid (eds), Viêt Nam: Borderless Histories (Madison, WI, 2006), pp. 219-255, 248. The poem was written in the Vietnamese character-based system.

40. It is unclear when this poem first circulated in Vietnam.

4I. "Tuyệt-chủng" is the phrase used here, indicating that the race suffered complete annihilation. Nguyễn, Chi sĩ Nguyễn Quang Diệu, p. 5 I.

42. The indigenous inhabitants of French Guiana included the Arawak, Carib, Teko, Kalina, Palikur, Wayampi, and Wayana. As well as the Amerindians, there was a population of maroons (descendants of runaway slaves).

43. Ideas of Social Darwinism were popular among Chinese and Vietnamese intellectuals at the time. 


\section{DENSE JUNGLE TOIL}

When they arrived in French Guiana, the group of four was assigned to a work unit to cut wood in an inland region, and Lý was placed as a guard in charge of his fellow prisoners. Putting Vietnamese prisoners in charge of other Vietnamese prisoners was also a feature of the prison system in Indochina, where so-called caplans, who were half-prisoner and half-guard, occupied this role. ${ }^{44}$ Convicts at work were not accompanied by guards. What is striking here is borne out in other writings on the bagne, which is simply that the penal colony of French Guiana was understaffed. In Beyond Papillon, historian Stephen Toth argues that "physical violence and punishment of the body was ever present" in French Guiana. ${ }^{45} \mathrm{He}$ also argues that the penal colony was severely lacking in personnel. ${ }^{46}$ Contradictions abound. Physical punishment was undoubtedly part of the regime of the penal colony, but its omission from the recollections of the $\mathrm{KDHH}$ is striking. As is the absence of the guards, and their sadism, which figured so predominantly in French memoirs. ${ }^{47}$ There are two ways to think about this: firstly, that Diêu and Lý wanted to represent themselves as more autonomous and with greater agency than was actually the case. Secondly, that they were essentially left unguarded on the premise that escape was impossible and, as mentioned before, the number of guards was insufficient. ${ }^{8}$ The idea of spreading out convicts to labour in small work crews also meant it was difficult to guard them. ${ }^{49}$

Due to his caplan position, Lý could slip away from the camp and was able to go to Cayenne at night to mix with the Chinese community. His many years of education in Hong Kong meant that, even though he was the youngest member of the four, Lý spoke English, Cantonese, and French fluently. His Cantonese came in especially useful; he was able to get medicine, non-prison clothing, and send and receive letters clandestinely. ${ }^{5 \circ}$ Convicts were dressed in distinctive grey clothing that made escape harder; medicine was also vitally important because of the rampant diseases of the penal colony.

44. Zinoman, Colonial Bastille, pp. I I I-I I 2. A similar system was also used in British penal sites in South Asia and also for Javanese exiles to Cape Town. There, convicts could wield power as "company police". See Kerry Ward, Networks of Empire: Forced Migration in the Dutch East India Company (Cambridge, 2009).

45. Toth, Beyond Papillon, p. I53.

46. Ibid. See ch. 4, "The Lords of Discipline: The French Penal Colony Service”, pp. 59-82.

47. Michel Le Clère, La Vie Quotidienne dans Les Bagnes (Paris, 1973), p. 94, discusses the sadism of the guards.

48. The situation of the guards before and after an I 867 decree formed them into a kind of corps of overseas prison guards, recruited predominantly from former non-commissioned army and navy personnel. See Toth, Beyond Papillon, p. 76.

49. Toth discusses the small work crew policy. See ibid., p. 78.

50. Nguyễn, Chi sĩ Nguyễn Quang Diệu, p. 56. 
These affinities with the Chinese world meant that the landscape of the penal colony had a different cultural legibility to him than to most of the inmates. In colonial Cayenne, indeed throughout French Guiana, Chinese trading communities (many Cantonese-speaking) were intimately woven into the fabric of penal colony society. Most had migrated from Shanghai and Canton, and as "commercial possibilities such as running a small store failed to attract many Creoles, it opened the way for Chinese domination of the small-scale retail market". ${ }^{\mathrm{I}}$ Indeed, the term "Le Chinois" came to mean "corner market" in Guyanese French. Chinese were renowned for selling everything from "champagne to sun-helmets". ${ }^{22}$ Anecdotal accounts from both prisoners and visitors to the penal colony indicate that Chinese traders throughout French Guiana acted as conduits for the sending of (unauthorized) correspondence, and not just for Vietnamese prisoners. ${ }^{53}$ Although an anecdotal observation, one visitor noted that "it is surprising what knowledge these Chinese possess of certain convicts, through acting as the medium by which letters are sent and received. Often they know more about the men than the authorities". ${ }^{4}$ Lý claimed he mingled with this Chinese community on almost nightly visits.

Meeting a young Cantonese speaker, educated at the prestigious St Joseph's College of Hong Kong, must have been an unexpected encounter to these Chinese, many of whom had emigrated from areas with which Lý was very familiar. Diêu also portrayed the exiles as being connected to global events through Lýs contacts in Cayenne, who told him of the progress of World War I and the exile to Réunion of the former Vietnamese Emperor Thành Thái and his son Emperor Duy Tan. The news of these other exiles inspired them, raising hopes that the need to exile the emperor indicated France's weakened condition. ${ }^{55}$ On the premise that France's position in Indochina was compromised due to its involvement in the war, it seemed an opportune moment to attempt escape. ${ }^{56}$

51. Redfield, Space in the Tropics, p. 217. In discussing the I990s, Redfield also mentions that " $[t]$ he Chinese, despite their relatively small numbers, occupy a position of social prominence as a result of their near-monopoly on small stores and related commerce", p. 44. Although this is a contemporary assessment, the "near-monopoly" (if not the "social prominence") would hold true for the colonial period. The observation about the breadth of their stock selection was made by William Edwin Allison-Booth, Hell's Outpost: The True Story of Devil's Island by a Man Who Exiled Himself There (New York, I931), p. I3.

52. Redfield, Space in the Tropics, p. 292.

53. Allison-Booth, Hell's Outpost, p. 28. Peter Redfield discusses this memoir and some of its dubious claims, in Space in the Tropics, pp. 93-94.

54. Allison-Booth, Hell's Outpost, p. 199. This is echoed in William Willis, Damned and Damned Again (New York, 1959), p. I23.

55. Thành Thái had already been imprisoned from 1907-1916 for displaying signs of madness to the French. CAOM, GGI-22 I 38 , details the symptoms.

56. Nguyễn, Chi sĩ Nguyễn Quang Diệu, p. 72. 


\section{TAFIA DREAMS OF ESCAPE}

Anecdotal accounts indicate that prisoners in French Guiana had two fixations to help them endure the penal colony: "tafia [cheap homebrewed rum] and the hope of escape". 57 Anthropologists, social scientists, and historians may differ in their opinions about aspects of the penal system in French Guiana; however, there is one fact on which they all agree: escape was difficult and dangerous. Anthropologist Peter Redfield estimates non-returned escapees at between two and three per cent of the prison population, but it is impossible to know how many made it to a safe locale. ${ }^{58}$ Historian Stephen Toth simply states: "To flee was a truly remarkable feat." "9 Or, to be more precise, to flee successfully was a truly remarkable feat. Even if the guard system was understaffed there were "two constantly watching guards who are always at their post: the jungle and the sea". ${ }^{6}$ French Guiana for the most part operated as a prison without walls in which the lack of money, travel documents, non-prison clothing, and access to a seaworthy boat or raft all precluded escape. Even if acquiring the necessities for escape was possible, trusting both your co-conspirators and a boat captain (if involved) was vital. ${ }^{6 \mathrm{I}}$ Maps of South America carried a huge premium. Lack of geographical knowledge made many prisoners dependent on prison rumour to understand the surrounding terrains. ${ }^{62}$ Lý had access to many necessities, including maps, through his Chinese contacts in Cayenne. ${ }^{63}$

Several possible escape routes existed and "the most common was to head northeast into what was then Dutch Guiana, either through the jungle or floating on a raft" ${ }^{64}$ However, escaped prisoners carried a one-hundredfranc capture award, an inducement for Amerindians living in the area. ${ }^{65}$ To reach Brazil, British Guiana, Venezuela, or Trinidad was even harder. ${ }^{66}$ Often, attempts to reach Trinidad ended in death - the sea could be rough

57. Convicts referred to Cayenne as "Tafiatown" as numerous shops there sold it. Belbenoit, Dry Guillotine, p. 2 19.

58. Redfield, Space in the Tropics, p. 80. The highest rate of successful escapes in one year was approximately five per cent, but that was exceptional. Redfield is drawing on the statistical analysis of French historians to make this statement.

59. Toth, Beyond Papillon, p. 57.

60. Belbenoit, Dry Guillotine, p. 54 .

6r. In one particularly notorious incident, a shipowner in Cayenne claimed he was taking convicts to Brazil and drowned them en route.

62. This comes up in various accounts of the penal colony. For example, Belbenoit, Dry Guillotine, p. 45 , talks in detail about the difficulties of finding out geographical information.

63. Nguyễn, Chi sĩ Nguyễn Quang Diệu, p. 32.

64. Redfield, Space in the Tropics, p. 80.

65. Jean-Pierre Fournier, Bonjour les Bagnes de Guyane. L'Amazonie Française. La Vie des Forçats de St-Martin-de-Ré à la Guyane (Paris, I999), p. 24.

66. In French Guiana and New Caledonia, the doublage law meant permanent exile for French convicts sentenced to over eight years. 
and difficult to negotiate without skilled nautical expertise - or in extradition. In I93 I, a law was passed in Trinidad to stop escapee extraditions to French Guiana because of British concern over conditions in the penal colony, but that was comparatively late for most prisoners. ${ }^{67}$ An unsuccessful escape meant solitary confinement for a period of time, and between two and five additional years of forced labour added to the original sentence. This penalty increased over time as more prisoners attempted to escape. ${ }^{68}$

It could be argued that it was not altruism, a fictive sense of kinship, or racial solidarity that motivated the Chinese in Cayenne to assist Lý and his friends in their escape. Rather, there was recognition that members of the $\mathrm{KDHH}$ had both linguistic and business acumen, marketable commodities in the transcolonial South American/Caribbean world. The prisoners were all literate in Chinese, Lý was fluent in English, and they participated in commercial enterprises to raise funds for the $\mathrm{KDHH}$. They were potentially valuable assets among overseas Chinese networks. On the other hand, the Chinese in Cayenne who facilitated their escape from French Guiana did not benefit directly from their escape in terms of either labour or skill. Instead, these Chinese residents jeopardized their permission to live and work in French Guiana. Acting as a postal service for prisoners was certainly unauthorized, but a blind eye could be turned; facilitating the flight of hardlabour political deportees was definitely a different level of assistance.

Aiding prisoners to escape would have elicited severe repercussions from the prison authorities. A sense of affinity to the group, perhaps especially to Lý due to his many years in Hong Kong, may have induced them to assist; it was rare for the Chinese communities to assist in helping so-called bagnards (penal colony convicts) escape. As one memoir mentions, some Chinese near the river in St Laurent du Maroni would undertake to arrange escapes in return for a suitable bribe, but such an arrangement was expensive. ${ }^{69}$ Indeed, there were groups better known for providing this kind of assistance - e.g. Brazilian ship captains and crew.

Two differing accounts have the group leaving for Trinidad in a "native" fishing boat as well as a Chinese-owned boat. However, in both accounts they were disguised as members of the Chinese community in Cayenne, with their passage paid for by that community. ${ }^{70}$ For the members of the $\mathrm{KDHH}$, racial masquerading was a skill perfected in their years travelling between China and Vietnam. As for the British authorities in Trinidad, one

67. In I 876, the British consul in Trinidad reported that the Chinese labourers in French Guiana suffered "barbarous and inhuman treatment".

68. These penalties were modelled on those imposed in metropolitan French prisons.

69. See George John Seaton, Isle of the Damned: Twenty Years in the Penal Colony of French Guiana (New York, I95 I), p. I I I.

70. Nguyễn Đình Đầu, "Nguyễn Quang Diêu: Một Kiếp Thề Ghi Với Nước Non”, Nhà Lao Annam ở Guyane (Ho Chi Minh City, 2008), p. 87, claims it was a "native” fishing boat. 
Asian looked pretty much like the next. Probably because of its small population and relative underdevelopment, Trinidad offered greater economic opportunities to ex-indentured Chinese, and about 3,000 Chinese left French Guiana and relocated there in the 1870 s and I 880 s. $^{71}$ In Trinidad itself, the Chinese had moved off the plantations and into trade as early as the 1870 s. $^{72}$ This meant there were strong connections between Chinese communities in Trinidad and French Guiana, and may explain why the Chinese in Cayenne were able to facilitate contacts in Port of Spain. Many Chinese Christians had converted in the West Indies or elsewhere prior to coming to Trinidad. ${ }^{73}$ This impacted how they were viewed within the colonial hierarchy as they were assessed positively in contrast to the Indians or Africans. ${ }^{74}$ Therefore, relations between the Chinese community and the British authorities were generally good and the addition of a few more Chinese members to their ranks would not have elicited comment. Indeed, Diêu mentioned that the group knew very little about this English tobacco island called "Tri-li-ni-dich" island, except that there was a large Chinese community there. The Chinese contacts who facilitated their escape gave the men letters of introduction to Chinese businesses in Port of Spain, Trinidad. It is unclear how much these Chinese employers in Port of Spain knew of the background of their new employees. An I 886 ordinance meant that all those suspected of being escapees from French Guiana were meticulously photographed, fingerprinted, and their physical appearance documented in detail by British authorities. ${ }^{75}$ Their details were then sent to the French authorities in Cayenne for verification. Several of the prisoners picked up were still in prison uniform or clearly had no travel documents, problems that this group did not encounter. ${ }^{76}$ It is undoubtedly true that dishevelled white men were more identifiable as escapees from the penal colony than "Chinese" travellers among a group of Chinese traders.

Once they arrived in Port of Spain, the men worked "undercover" of being Chinese in different Chinese companies. Diêu worked for an Anglo-Chinese

7r. Bridget Jones and Elie Stephenson, "Society, Culture and Politics in French Guiana", in Richard D. E. Burton and Fred Reno (eds), French and West Indian: Martinique, Guadeloupe, and French Guiana Today (London, 1995), p. 67.

72. Andrew R. Wilson (ed.), The Chinese in the Caribbean (Princeton, NJ, 2004), Introduction, p. I 8.

73. Kim Johnson, Descendants of the Dragon: The Chinese in Trinidad I806-2006 (Kingston, 2006), p. 62.

74. See Anne-Marie Lee-Loy, "Kissing the Cross: Nineteenth-Century Representations of Chinese and Indian Immigrants Chinese in British Guiana and Trinidad", in Wilson, The Chinese in the Caribbean, pp. $25-40$.

75. CAOM, H/5354. The lists of escapees sent to the British in Trinidad from French Guiana do not include any of the names of the group in any year between I9Is and 1919, so they did not come to colonial attention in Trinidad.

76. CAOM, H/5354, Dossiers of the Escapees in British Custody in Trinidad. 
commercial firm. Lý married the unnamed English woman he met through the Chinese business that employed him - an interracial marriage facilitated by his fluency in English. The fact that his wife never realized he was Vietnamese, or an escapee from French Guiana, may demonstrate that his true identity did not circulate within his Chinese firm in Port of Spain. Given Trinidad's extradition policies, discretion was essential and Lý took that discretion even into the matrimonial home. After Lý married, he was able to borrow money from his wife's family and set up a small store, which he and his wife ran together. ${ }^{77}$

In his recollections, Lý discussed how, on the day he left, when his wife and children were visiting her parents, he removed some of their joint savings to assist with his passage from Port of Spain. "He was not able to speak one sentence to say goodbye, but left and was separated from her forever." 78 The Chinese community in Port of Spain raised funds to facilitate four passages, which the group supplemented from their savings. ${ }^{79}$ They left Trinidad in I 920 or I92 I and spent the next few years in various locations in southern China.

Little is known of Lýs precise activities over the next few years based in southern China and Hong Kong. However, in I929, Lý decided to return to Vietnam. Ironically, this ultimately led to his rearrest in the city of Vinh Long in southern Vietnam four years later. In I933, a colonial tribunal found him guilty of fomenting rebellion and sentenced him to fifteen years' hard labour on the prison island of Poulo Condore (off the southern coast of Vietnam). Established in $\mathrm{I} 86 \mathrm{I}$, prior to the consolidation of French Indochina, Poulo Condore was a notorious penal site for prisoners from all the territories of French Indochina. As historian Peter Zinoman points out, "[T] he intensity of the Vietnamese resistance [against the French] generated demands for fortified camps where anticolonial leaders and prisoners of war could be locked away" ${ }^{80}$ That fortified place was Poulo Condore, where thousands of Vietnamese prisoners died during the colonial period. Lý died there, shortly after his sentencing, at the age of forty.

Although Diêu claimed that, in I92 I, he returned to China and Vietnam via the United States and visited Washington DC, there is no evidence to corroborate that this was indeed the route taken. ${ }^{81}$ When Diêu reached Canton he met up with many members of the exiled Vietnamese community and wrote a pamphlet, Việt Nam cách mạng lưu vong chư

77. Very little can be found out about the couple's marriage or the store that they established together. This information comes from the interviews that Nguyễn Văn Hầu conducted with people who had known him.

78. Nguyễn, "Lý Liễu và phong trào đại đông du", p. 47.

79. Idem, Chi sĩ Nguyễn Quang Diệu, p. 62.

80. Zinoman, Colonial Bastille, p. 29.

81. Nguyễn, Chí sĩ Nguyễn Quang Diệu, p. 58. 
nhân vật [Vietnamese Revolutionary Exiles] in Chinese. ${ }^{82}$ On his return to Vietnam, he published poetry and political treatises, which circulated widely in the Mekong Delta at the end of the 1920s. ${ }^{83}$ Diêu was never rearrested.

Lý Liễu and his colleagues were not the only Vietnamese group to escape French Guiana through Chinese contacts. Between 1907 and 1924, another thirteen members of groups attached to "new learning" groups escaped from French Guiana to Trinidad with Chinese assistance. Ironically, the four members of the KDHH may have passed by these other Vietnamese escapees from French Guiana in the streets of Port of Spain unaware of their racial origins, or entertaining suspicions but not wanting to draw attention to themselves. ${ }^{84}$ Not as much is known about the members of these other groups, except for information from the grandson of one of the escapees, Đô̂ Văn Phong. ${ }^{85}$ No year of escape was narrated to his family, just that in Trinidad "a number of Chinese people protected him". ${ }^{86}$ However, it was prior to 1924 because it was then that his family got news of his escape to Port of Spain, where he pretended to be a practitioner in Chinese herbal medicine after establishing a small business. ${ }^{87}$ Đỗ eventually returned safely to Vietnam and became a successful publisher.

Perhaps from the perspective of a Western historian, Lý Liễu's decision to return to Hong Kong, and eventually Vietnam, marked a tragic turn in his tale that ended in his untimely death in Poulo Condore. However, for the only Vietnamese historian who has written about Lý Liễu, the real tragedy is Lýs endlessly restless spirit. The fact that his half-English, halfVietnamese children in Trinidad were unable to place a grave in his natal village means a spirit who will never be at peace and who will ceaselessly haunt the penal vestiges of Poulo Condore. ${ }^{88}$ There is no marker of his grave, no artefact connecting him to his natal village, a different kind of "marker" than Western historians seek.

Narratives of prisoners within French penal flows can often be reconstructed from the extensive extant archives at the Centre des Archives d'Outre Mer in Aix en Provence. Lý Liễu's is not one of them. He makes only three very brief appearances in an official archive. He appears at the times

82. In this title, he uses the word lun vong to mean "in exile".

83. For a translation of this exhortation see Hue-Tam Ho Tai, Millenarianism and Peasant Politics in Vietnam (Cambridge, MA, I983), pp. 178-179.

84. This is speculative, because Đố Văn Phong and the other escapees may have arrived after the KDHH members had left.

85. The story of Đỗ Văn Phong was related by his grandson, Đỗ Thái Bình, to Huỳnh Thanh Bình, "Một Kiếp Thề Ghi Với Nước Non", in Nhà Lao An Nam Ở Guyane, p. Io4.

86. Ibid.

87. Ibid.

88. Bách Khoa, CXXXXV, pp. 39-49. Poulo Condore is now known as Con Son Island and has both a national park and a luxury resort on it. 
of sentencing - I91 3 and 1933 - and he appears briefly in the private papers of Gaston Liebert, the French consul in Hong Kong at the time of his arrest. Although there are voluminous files in the French archives on French Guiana, Lý Liễu's story also shows the lacunae of the archives and the need to read widely in different contexts in order to piece together a multinational narrative of a very cosmopolitan prisoner. Traces of his life had to be carefully reconstructed from historical strands and in Vietnamese and Chinese texts so that his hidden life, one far from the eye of colonial surveillance, could be told. Lý Liễu's life history illustrates the necessity of going beyond the apparatus of the archive to explore penal circulations and connections not readily apparent, and the vital importance of transcending national and/or colonial textual and archival boundaries to examine both the constraints on, and mobility of the lives of, transcolonial exiles. 